\title{
EFFECT OF GROWTH CONDITIONS ON BIOSORPTION OF CADMIUM AND COPPER BY YEAST CELLS
}

\author{
V.A. ANAGNOSTOPOULOS \\ B.D. SYMEOPOULOS* \\ M.J. SOUPIONI
}

Received: 04/06/10

Accepted: 13/09/10

\author{
University of Patras \\ Department of Chemistry \\ Radiochemistry lab \\ Patras 26500, Greece
}

\begin{abstract}
The dependence of $\mathrm{Cd}(\mathrm{II})$ and $\mathrm{Cu}(\mathrm{II})$ uptake by yeast cells on the age and temperature of cell culture was studied. Saccharomyces cerevisiae, Kluyveromyces marxianus and Debaromyces Hansenii were chosen as typical yeasts, while $\mathrm{Cd}(\mathrm{II})$ and $\mathrm{Cu}(\mathrm{II})$ as typical metal pollutants. Our results revealed that higher metal uptake was obtained by cells grown at the optimum temperature $\left(30{ }^{\circ} \mathrm{C}\right)$ of cell culture. It was also found that the exponential phase cells resulted in a higher metal uptake than the stationary ones. A first interpretation of relevant bibliographic data concerning the effect of growth phase on metal uptake is proposed, assuming that limited qualitative changes in the cell wall structure take place as the cells pass from exponential to stationary phase, in addition to quantitative modifications, which have been reported in the literature. According to our interpretation the relative abundance among quantitative and qualitative alterations of cell wall, determines if stationary or exponential cells attain the higher metal binding capacity. An indication supporting our approach may be the fact that our hypothesis implies a decrease of $\mathrm{p} K_{a}$ values of cell wall carboxyl groups with the age of cells, which is consistent with data reported by other authors.
\end{abstract}

KEYWORDS: uptake, removal, Saccharomyces cerevisiae, Kluyveromyces marxianus, Debaromyces Hansenii, growth phase, growth temperature.

\section{INTRODUCTION}

Water pollution, due to heavy metals, is a serious worldwide problem. Cadmium is a heavy metal, which poses serious health hazards through entry into the food chain (Vasudevan et al., 2003). Copper is another heavy metal with many industrial applications (Konstantinou and Pashalidis, 2008). Although it is an essential element, WHO has established a limit of $2 \mathrm{mg} \mathrm{L}^{-1}$ as the maximum acceptable concentration in drinking water.

Aiming at removal of heavy metals, numerous attempts have been made to treat wastewaters by traditional methods such as, chemical precipitation, lime coagulation, ion-exchange, reverse osmosis, membrane separation, adsorption onto active carbon, e.t.c. However, all these methods have shown varying performances, often incomplete metal removal, especially in low concentration pollutant range, high energy requirements, high capital investment and operating costs (Grimm et al., 2008; Vázquez et al., 2009; Chojnacka and Michalak, 2009).

On the other hand, it is known that various microorganisms efficiently adsorb dissolved metal ions (Volesky, 2003). Exploitation of this phenomenon suggests a potential use of microorganisms, in the remediation of metal-containing waste waters (Volesky and Holan, 1995), in the recovery of precious entities, such as gold (Umali, et al., 2006), or in the treatment of radionuclides for reasons related to Radioactive Waste Management (Vlachou et al., 2009; Sarri et al., 2009). Diverse microorganisms, such as algae (Herrero et al., 2008; Lodeiro et al., 2006), fungi (Arica et al., 2001), bacteria (Ozdemir 
et al., 2004) and yeasts (Vlachou et al., 2009; Sarri et al., 2009), have been investigated, as an alternative way for removing toxic metals from aqueous solutions. Because some microorganisms may derive as by-products or even waste materials from industry or agriculture, are commonly considered as inexpensive biosorbents, like other naturally abundant materials (Carro et al., 2010; Hawari and Mulligan, 2006; McKey et al., 1999; Volesky 2003). Therefore, the major advantage of their use is the achievement of high purity of the treated wastewater associated with low cost.

In all studies dealing with the interaction of microorganisms with heavy metals or radionuclides, a few certain parameters have been investigated e.g., the solution pH (Göksungur et al., 2005), the ratio of sorbent to solution concentration (Vasudevan et al., 2003), the temperature of the procedure (Xie, et al., 2008), the ionic strength and the presence of coexistent metals or ligands (Das et al., 2002), the chemical modification of the biomass and the surface properties of the organism, such as surface area (e.g. Bai and Abraham, 2002).

However, microorganisms are living organisms and the concentrations of their cell wall functional groups are not fixed, as they depend on their growth physiology and metabolic state (Daughney et al., 2001; Andrès et al., 2001). Hence, the surface characteristics of microorganisms can vary with their age. Consequently, the age of the cells, which is directly related to the growth phase from which the cells were isolated, could affect the metal uptake. In addition, it is known (Russell, 2002) that the composition of membranes alters with the growth temperature and so this may affect metal uptake. Up to now, such biotic or environmental variables, affecting $\mathrm{Cu}(\mathrm{II})$ and $\mathrm{Cd}(\mathrm{II})$ uptake by yeast cells, have not been studied.

The objective of the present study was to explore the possible dependence of $\mathrm{Cd}(\mathrm{II})$ and $\mathrm{Cu}$ (II) uptake from aqueous solutions on some critical growth conditions of yeast cells; the biomass age and temperature of cell culture. Saccharomyces cerevisiae, Kluveromyces marxianus and Debaromyces hansenii were selected as typical yeasts involved in various common industries, such as breweries, wineries (Iconomopoulou et al., 2002; Kourkoutas et al., 2001; Kopsahelis et al., 2007), bakeries (Bekatorou et al., 2006; Plessas et al., 2008) and industries of dairy products (Koutinas et al., 2009) and therefore, as industrial by-products, could be considered as low cost biosorbents.

\section{METHODS}

\section{Biomass preparation}

Commercial strains of $K$. marxianus and D. hansenii were purchased from Chr. Hansen A/S, Denmark, under the code names LAF-4 and LAF-3 respectively, while $S$. cerevisiae cells were grown from a commercial product of baker's yeast ("L' hirondelle"), purchased from a local market. All yeasts were cultivated, under gentle stirring, in the same sterilized nutrient medium (temperature $=121{ }^{\circ} \mathrm{C}$, pressure $=1.1 \mathrm{~atm}$ for $15 \mathrm{~min}$ in autoclave), consisting of $40 \mathrm{~g} \mathrm{~L}^{-1}$ glucose, $4 \mathrm{~g} \mathrm{~L}^{-1}$ yeast extract (Merck), $1 \mathrm{~g} \mathrm{~L}^{-1} \mathrm{KH}_{2} \mathrm{PO}_{4}, 1 \mathrm{~g} \mathrm{~L}^{-1}\left(\mathrm{NH}_{4}\right)_{2} \mathrm{SO}_{4}$ and $10 \mathrm{~g} \mathrm{~L}^{-1} \mathrm{MgSO}_{4} \cdot 7 \mathrm{H}_{2} \mathrm{O}$ at 30 and $15^{\circ} \mathrm{C}$.

The growth of each microorganism was monitored by measuring periodically, the optical density of small volume samples withdrawn from the cell culture. The optical density was measured at $700 \mathrm{~nm}$, against sterilized nutrient medium, which served as reagent blank (Madigan et al., 2000). The values of optical density measured were correlated with the concentrations of cells, in terms of dry weight of cells per litre of suspension $\left(\mathrm{g} \mathrm{L}^{-1}\right)$ by appropriate calibration curves. These curves had been obtained by measuring the optical density of lyophilized cell suspensions of known concentrations, which had just been prepared and homogenized in the sterilized nutrient medium. It is known that during the progress of a cultivation process, just after the initial lag phase, the exponential or logarithmic phase of growth follows, which is characterized by an abrupt growth rate, followed by the stationary phase, which is characterized by a constant cell number. Through the plot of biomass concentration against time, the exponential and the beginning of stationary phase were determined accurately. Based on these kinetic data of incubation, independent cell populations for each one microorganism were isolated from the nutrient medium by centrifugation (4000 rpm, 15-20 min), at three different time intervals :

i) approximately, in the middle of the exponential phase, denoted as exponential phase

ii) at the beginning of the stationary phase, denoted as early stationary phase and

iii) after a time interval, about 2 to 4 times longer than that determined as early stationary phase, which was denoted as late stationary phase. 
After the planned period of growth, the isolated biomass was washed twice with deionized-sterilized water $(18 \mathrm{M} \Omega$ ) via sequential resuspensions-centrifugations, to remove the excess of nutrient medium. Then, the biomass was lyophilized and finally was stored at $-20{ }^{\circ} \mathrm{C}$. The cells were lyophilized, as they can not be dried by conventional methods. So heating in an oven, generates a relative thick surface layer, which keeps wet the rest of the biomass. Lyophilisation is the most effective way of preserving cells, which is widely used in many biotechnological applications (Bekatorou et al., 2001; Bekatorou et al., 2002).

\section{Sorption experiments}

For sorption experiments, stock solutions of $\mathrm{Cd}(\mathrm{II})$ and $\mathrm{Cu}(\mathrm{II})$ were prepared from a standard 1000 $\mathrm{mg} \mathrm{CdCl} 2$ (Merck, catalogue number 109960) and an AAS standard Copper(II) $1000 \mu \mathrm{gL}^{-1}$ (Alfa Aesar, catalogue number 088061) respectively. Fresh working solutions were prepared by diluting appropriate portions of the stock solution with triply distilled water.

Batch sorption experiments were carried out by suspending $0.10 \mathrm{~g}$ of lyophilized cells, in $10.0 \mathrm{~mL}$ of $\mathrm{Cd}(\mathrm{II})$ or $\mathrm{Cu}(\mathrm{II})$ solution with initial concentration $100 \mathrm{mg}$ metal $\mathrm{L}^{-1}$ at $\mathrm{pH} 4$, which favors sorption process (Hawari and Mulligan, 2006; Lu and Gibb., 2008).

The biomass and the sorbate were agitated for 24 hours, as many authors have reported that the kinetics of metal uptake by microorganisms is a fast procedure (Markai et al., 2003; Daughney et al., 1998). It is a common practice, 24 hours to be considered as a safe and adequate period of time in order equilibrium to be attained, whenever kinetic experiments are not carried out. After agitation for 24 hours, in a rotary shaker, the supernatant was isolated by centrifugation at $4000 \mathrm{rpm}$ for $10 \mathrm{~min}$. The residual metal concentration in the supernatant was determined by Flame Atomic Absorption Spectrometry (FAAS).

The results were expressed, as percentage of metal removal by using the following equation:

Metal removal $(\%)=\frac{\left(C_{i}-C_{f}\right)}{C_{i}} \times 100$

where, $C_{i}$ and $C_{f}$ stand for the initial and final metal concentration respectively. For each experiment, the mean value of three independent samples was reported.

\section{RESULTS AND DISCUSSION}

A typical calibration curve, used to correlate the optical density of lyophilized $D$. hansenii cell suspensions with known cell concentrations, is shown in Fig.1.

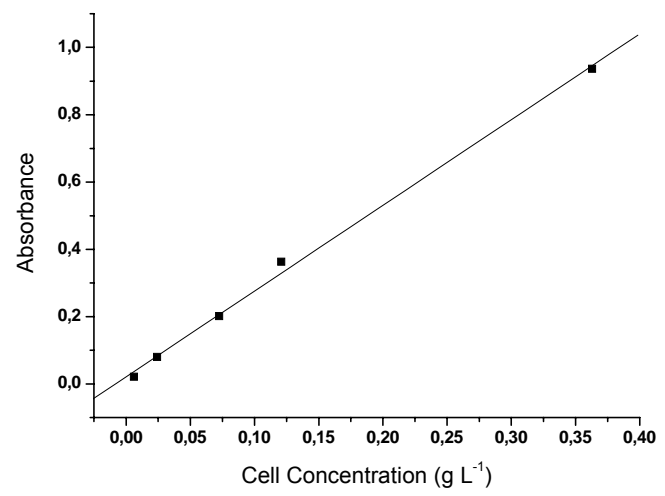

Figure 1. Typical calibration curve used to correlate optical density with biomass concentration. The calibration parameters were: $y$-intercept : $0.021 \pm 0.01$, slope : $2.6 \pm 0.1$ and $R^{2}=0.996$

Typical growth curves for $D$. hansenii at two different temperatures are shown in Fig. 2. The values of Fig. 2, are averaged from two independent cultures, grown simultaneously, under identical conditions. The growth curves of S. cerevisiae and $K$. marxianus at 30 and $15{ }^{\circ} \mathrm{C}$ (not shown), revealed similar behavior with those in Fig. 2. 


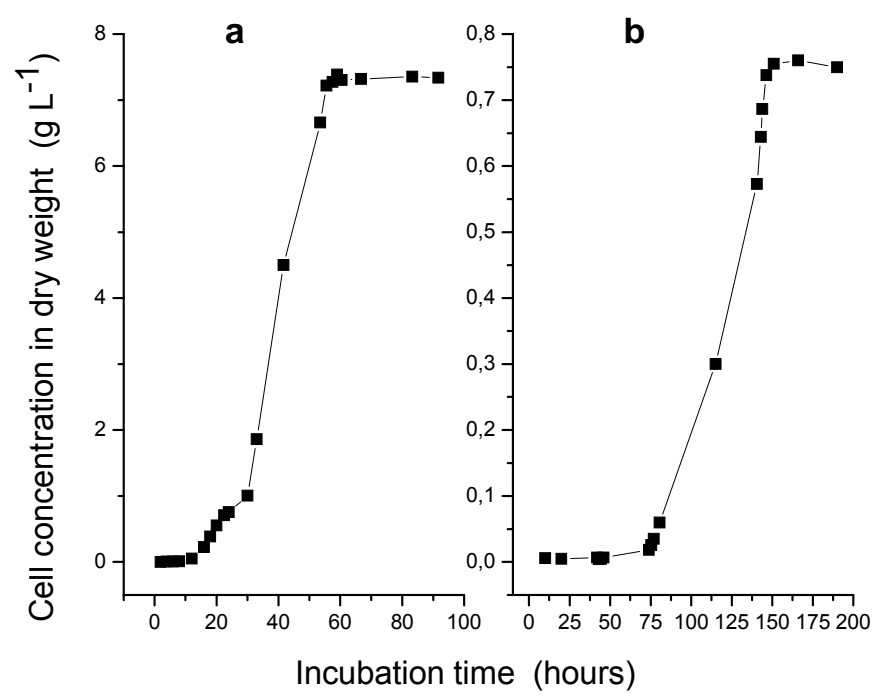

Figure 2. Growth curves of $D$. hansenii in terms of cell concentration against the time of incubation at $30{ }^{\circ} \mathrm{C}(\mathrm{a})$ and $a t 15^{\circ} \mathrm{C}(\mathrm{b})$. Note, that the scale of both axes in the two graphs, are different

Isolation times, used for each type of biomass under different temperatures, were compiled in Table 1. When the growth temperature of a microorganism is reduced, the initial lag phase extends, the growth rate decreases and the final cell number usually decreases (Beales, 2004). Our experimental growth curves, are consistent with these characteristics, as can be seen in Fig. 2 and in Table 1.

Table 1. Isolation times of different growth phases at 30 and $15^{\circ} \mathrm{C}$, for the three yeast cells studied

\begin{tabular}{|c|c|c|c|}
\hline \multirow[b]{2}{*}{ Type of Yeast } & \multirow[b]{2}{*}{ Growth Phase } & \multicolumn{2}{|c|}{ Isolation time (hours) } \\
\hline & & $\begin{array}{c}\text { Incubation at } 30{ }^{\circ} \mathrm{C} \\
\text { (optimum temperature) }\end{array}$ & $\begin{array}{c}\text { Incubation at } 15^{\circ} \mathrm{C} \\
\text { (below optimum temp) }\end{array}$ \\
\hline \multirow{3}{*}{ D. hansenii } & Exponential & 40 & 130 \\
\hline & Early stationary & 58 & 170 \\
\hline & Late stationary & 96 & 250 \\
\hline \multirow{3}{*}{ K. marxianus } & Exponential & 13 & 110 \\
\hline & Early stationary & 24 & 160 \\
\hline & Late stationary & 96 & 230 \\
\hline \multirow{3}{*}{ S. cerevisiae } & Exponential & 24 & 120 \\
\hline & Early stationary & 48 & 170 \\
\hline & Late stationary & 96 & 230 \\
\hline
\end{tabular}

The percentages of cadmium and copper removed by cells isolated from different growth phases and different temperatures for the three yeasts studied, are shown in Table 2.

From Table 2, it is clear that the harvesting growth phase of the biomass affects the metal uptake quantitatively. The above results indicate that the maximum uptake was obtained when the biomass had been harvested during the exponential phase. Moreover, for each one microorganism, during a cultivation process, either at $30^{\circ} \mathrm{C}$, that is the optimum growth temperature (Adams and Moss, 1997 ), or even at $15^{\circ} \mathrm{C}$, a progressive reduction of the uptake was observed, from exponential to late stationary phase.

Thus, from Table 2, it is apparent that:

i) the optimum temperature of growth yielded higher metal uptake and

ii) cells at the exponential phase achieved higher metal uptake than the stationary phase.

Beales (2004) and Russell et al., (1995) reported that the cell membrane of both bacteria and yeasts contain higher proportion of unsaturated fatty acids as the growth temperature decreases. As the temperature is reduced, a number of changes have also been reported such as an increase in cell size for Candida utilis (Beales, 2004), or formation of a double cell wall for Bacillus subtilis (Beales, 2004; Neale and Chapman, 1970). In addition, a number of less reported alterations can occur such 
Table 2. Removal of cadmium and copper depending on growth conditions for the three yeasts studied \pm standard deviation of triplicate experiments

\begin{tabular}{|c|c|c|c|c|c|}
\hline \multirow[b]{2}{*}{ Type of yeast } & \multirow[b]{2}{*}{ Phase } & \multicolumn{2}{|c|}{ Cd(II) removal (\%) } & \multicolumn{2}{|c|}{$\mathrm{Cu}(\mathrm{II})$ removal (\%) } \\
\hline & & $\begin{array}{c}\text { Incubation } \\
\text { at } \\
30^{\circ} \mathrm{C}\end{array}$ & $\begin{array}{c}\text { Incubation } \\
\text { at } \\
15^{\circ} \mathrm{C}\end{array}$ & $\begin{array}{c}\text { Incubation } \\
\text { at } \\
30^{\circ} \mathrm{C}\end{array}$ & $\begin{array}{c}\text { Incubation } \\
\text { at } \\
15^{\circ} \mathrm{C}\end{array}$ \\
\hline \multirow{3}{*}{ D. hansenii } & Exponential & $74 \pm 3$ & $65 \pm 2$ & $51 \pm 2$ & $42 \pm 2$ \\
\hline & Early stationary & $66 \pm 3$ & $52 \pm 1$ & $41 \pm 1$ & $32 \pm 1$ \\
\hline & Late stationary & $52 \pm 4$ & $42 \pm 1$ & $36 \pm 1$ & $25 \pm 2$ \\
\hline \multirow{3}{*}{ K. marxianus } & Exponential & $73 \pm 1$ & $61 \pm 1$ & $40 \pm 2$ & $40 \pm 2$ \\
\hline & Early stationary & $64 \pm 2$ & $52 \pm 2$ & $32 \pm 1$ & $28 \pm 2$ \\
\hline & Late stationary & $42 \pm 3$ & $42 \pm 1$ & $29 \pm 1$ & $21 \pm 1$ \\
\hline \multirow{3}{*}{ S. cerevisiae } & Exponential & $79 \pm 1$ & $60 \pm 1$ & $43 \pm 2$ & $36 \pm 2$ \\
\hline & Early stationary & $64 \pm 3$ & $46 \pm 1$ & $35 \pm 1$ & $25 \pm 1$ \\
\hline & Late stationary & $37 \pm 6$ & $30 \pm 1$ & $26 \pm 2$ & $14 \pm 3$ \\
\hline
\end{tabular}

as, shortening in the mean fatty acid chain length, which was reported for the yeast Zygosaccharomyces bailii (Beales, 2004; Baleiras Couto and Huis in 't Veld, 1995), an increase in the amount of branch fatty acids (Beales 2004), a reduction in the proportion of cyclic fatty acids (Russell et al., 1995), an increase of the anteiso branched fatty acid content and a decrease of the iso branched content (Beales, 2004). So, it is easily understood that the metal capacity of microorganisms grown at reduced temperature is associated with a great number of potential changes of membrane. As we shall explain later, for some cases of cell wall modifications, it may be possible for us to predict qualitatively, how a certain modification could affect the metal uptake. Nevertheless, the lack of quantitative information about the extent of each alteration, restricts our knowledge dramatically. At present, it is not possible to speculate how these changes could affect the metal uptake.

On the other hand, the dependence of metal uptake on growth phase seems to be a little more comprehensible. Since 1984, Norberg and Persson (1984) have reported the effect of culture age on the uptake of $\mathrm{Cd}(\mathrm{II})$ and $\mathrm{Cu}(\mathrm{II})$. Then, Shuttleworth and Unz (1993) noticed that metal (Ni(II) and $\mathrm{Zn}(\mathrm{II}))$ uptake was a function of cell age. The authors of both reports, did not study the uptake as a function of growth phase due to the lack of kinetics of growth. Hadi et al., (2003) investigated Cd(II) uptake by S. cerevisiae cells of different ages (harvested 24 and 72 hours after inoculation) and reported that the 72 hour cultivated cells had lower metal capacity than the younger cells. This result was explained by the change of the cell wall structure as a function of time.

The effect of growth phase is likely related to changes in the composition of the cell wall (Daughney et al., 2001). This composition, in turn, depends on the composition of the nutrient medium, which apparently, does not remain constant. As the population grows up, the ingredients of the growth medium are consumed, their concentrations are reduced and the exponential phase cells enter the stationary phase. The abundance of nutrients available to cells in the exponential phase, allow them to develop cell walls with high concentration of suitable binding sites. However, as the concentration of nutrients decreases and the population moves to the stationary phase, cell walls with lower densities of favourable binding sites are formed (Daughney et al., 2001). According to this aspect one could expect a quantitative difference in the composition of cell wall among exponential and stationary phase cells. This aspect implies that the metal capacity of exponential cells should be higher than stationary phase cells.

Macaskie and Dean (1984) observed that Cd(II) was most extensively adsorbed by Citrobacter sp., when the cells were in mid-exponential phase. Chang et al. (1997) reported that Cd(II) was most extensively adsorbed by exponential growth phase Pseudomonas aeruginosa cells. Daughney et al. (2001) reported that Bacillus subtilis cells in stationary phase adsorbed less $\mathrm{Cd}$ (II) and $\mathrm{Fe}$ (III), roughly $5-10 \%$, than cells in exponential phase. The results of this work, compiled in Table 2, are consistent with this behaviour.

In contrast, Friis and Meyers -Keith (1986) found that Streptomyces longwoodensis cells harvested during the stationary phase exhibited higher $\mathrm{U}(\mathrm{VI})$ capacity. Chang et al., (1997) reported that $\mathrm{Pb}(\mathrm{II})$ was most extensively adsorbed by early stationary phase Pseudomonas aeruginosa cells, while 
adsorption of $\mathrm{Cu}(\mathrm{II})$ was not affected by growth phase. Lower $\mathrm{U}(\mathrm{VI})$ binding uptake by Pseudomonas aeruginosa cells, was observed from cells in exponential phase than from stationary cells (Andrès et al., 2001).

The above mentioned reports indicate that a quantitative difference in the composition of cell membrane among exponential and stationary phase cells, as suggested by Daughney et al. (2001), is unable to explain existing data, as a whole. So, we have to assume another reasonable explanation. It seems probable, that the partial deficiency of some ingredients of nutrient medium during the final stages of exponential phase, could additionally cause limited qualitative changes in the composition of the membrane, which result in a decrease of the corresponding $\mathrm{p} K$ value of one or possibly more surface functional groups. For example, if a component of the cell wall is being formed under conditions of carbon deficiency (e.g. a carboxylic acid), one could expect a reduction in the length of its carbon chain. This type of qualitative changes will result in a slight variation of deprotonation constants $\left(\mathrm{pK}_{a}\right)$ of the corresponding functional group. Carboxyl groups, associated with cell wall surface components, are considered to be among the main groups of cell membrane responsible for metal binding (Daughney et al., 1998; Hong and Brown, 2006). A reduction in the length of a carboxylic acid carbon chain or even the formation of a double bond, is associated with a decrease of $\mathrm{p} K_{a}$ value, as this is the trend comparing the $\mathrm{p} K_{a}$ values of short-chain aliphatic carboxyl acids, e.g. formic-acetic acid, acrylic-propionic acid. It is worth noting that our assumption complies with the decrease of $\mathrm{pK}_{a}$ values of carboxyl groups observed by Daughney et al., (2001), as the cells of Bacillus subtilis passed from exponential to stationary phase. In metal uptake studies, slightly acidic or neutral solutions are generally used, since at higher $\mathrm{pH}$ values, precipitation of hydroxide may occur. A decrease in $\mathrm{pK}$ of some surface functional groups, will increase the negative charge density, because of the deprotonation of some binding sites and consequently, it will charge the cell membrane more negatively. An increase of negative surface charge in turn, favors the binding of cationic species and hence a higher metal binding capacity will be expected for stationary phase cells.

Therefore, as nutrient is depleted from the growth medium and the cells pass from exponential to stationary phase, apart from the quantitative changes in the composition of membrane reported in literature, we assume that limited qualitative changes in the cell wall take place in parallel, causing a decrease of $p K$ value of one or more functional groups. As we explained above, the quantitative changes suggest that cells in the exponential phase, due to higher concentration of suitable functional groups, should yield higher metal capacity than cells in the stationary phase. The opposite result is predicted by the qualitative changes of membrane, as suggested above.

Obviously, the relative abundances between the two kinds of membrane alterations, determine which cells (exponential or stationary) attain the higher metal capacity. Therefore, according to our approach, bibliographic data, which at first glance, seem to be in contradiction, can become a little more comprehensible.

\section{CONCLUSIONS}

Our results revealed that the optimum temperature of growth yields higher $\mathrm{Cd}$ (II) and $\mathrm{Cu}$ (II) uptakes and additionally that exponential cells of the three yeasts attain higher metal capacity than stationary phase cells. The lack of quantitative information about the extent of each alternation and the great number of membrane changes caused by variation of the temperature of cell culture, restrict our ability to predict the effect of this parameter on metal uptake.

As far as the influence of growth phase on metal uptake is concerned, the general literature aspect is that the effect of growth phase seems to be metal- and species- specific. To the best of our knowledge, no more recent explanation has been attempted. By this work, we propose a qualitative interpretation of relevant bibliographic data.

\section{ACKNOWLEDGEMENTS}

The authors gratefully acknowledge Professor $P$. Ioannou for the improvement of the text, Lecturer A. Bekatorou and Dr. L. Bosnea for providing knowledge on biomass preparation and the two unknown reviewers of this manuscript for their helpful criticisms. We also thank the European Social Fund (ESF), Operational Program for Educational and Vocational Training II (EPEAEK II), and particularly the Program PYTHAGORAS II, for funding the above work. 


\section{REFERENCES}

Adams M.R. and Moss M.O. (1997) Food Microbiology, The Royal Society of Chemistry, Cambridge, 43

Andrès Y., Redercher S., Gerente C. and Thouand G. (2001) Contribution of biosorption to the behavior of radionuclides in the environment, J. Radioanal. Nucl. Chem., 247(1), 89-93

Arıca M.Y., Kaçar Y. and Genç Ö. (2001) Entrapment of white-rot fungus Trametes versicolor in Caalginate beads: preparation and biosorption kinetic analysis for cadmium removal from an aqueous solution, Bioresour. Technol., 80(2), 121-129.

Bai R.S. and Abraham T.E. (2002) Studies on enhancement of $\mathrm{Cr}(\mathrm{VI})$ biosorption by Chemically modified biomass of Rhizopus nigricans, Water Res., 36(5), 1224-1236.

Baleiras Couto M.M. and Huis in't Veld J.H.J. (1995) Influence of ethanol and temperature on The cellular fatty acid composition of Zygosaccharomyces bailii spoilage yeasts, J. Appl. Bact., 78(3), 327-333.

Beales N. (2004) Adaptation of Microorganisms to Cold Temperatures, Weak Acid Preservatives, Low $\mathrm{pH}$, and Osmotic Stress: A Review, Compr. Rev. Food Sci F., 3(1), 1-20.

Bekatorou A., Koutinas A.A., Kaliafas A. and Kanellaki M. (2001) Freeze-dried Saccharomyces cerevisiae cells immobilized on gluten pellets for glucose fermentation, Process Biochem., 36, 549557.

Bekatorou A., Soupioni M.J., Koutinas A.A. and Kanellaki M.E. (2002) Low-temperature brewing by freeze-dried immobilized cells, Appl. Biochem. Biotech., 97, 105-121.

Bekatorou A., Psarianos C. and Koutinas A.A. (2006) Production of Food Grade Yeasts, Food Technol. Biotech., 44(3), 407-415.

Carro L., Anagnostopoulos V., Lodeiro P., Barriada J.L., Herrero R. and De Vicente E.S. (2010) A dynamic proof of mercury elimination from solution through a combined sorption- reduction process. Bioresour. Technol., 101(23), 8969-8974.

Chang J.-S., Law R. and Chang C.-C. (1997) Biosoprtion of lead, copper and cadmium by Biomass of Pseudomonas aeruginosa PU21, Water Res., 31(7), 1651-1658.

Chojnacka K. and Michalak Z. (2009) Using wood and bone ash to remove metal ions from solutions, Global NEST Journal, 11(2), 205-217.

Das S.K., Kedari C.S., Shinde S.S., Ghosh S. and Jambunathan U. (2002) Performance of immobilized Saccharomyces cerevisiae in the removal of long lived radionuclides from aqueous nitrate solutions, J. Radioanal. Nucl. Chem., 253(2), 235-240

Daughney C.J., Fein J.B. and Yee N. (1998) A comparison of the thermodynamics of metal adsorption onto two common bacteria, Chem. Geol., 144(3-4), 161-176.

Daughney C.J., Fowle D.A. and Fortin D. (2001) The effect of growth phase on proton and Metal adsorption by Bacillus subtilis, Geochim. Cosmochim. Acta, 65(7), 1025-1035.

Friis, N. and Meyers-Keith P. (1986) Biosorption of uranium and lead by Streptomyces Longwoodensis, Biotech. Bioeng., 28, 21-28.

Göksungur Y., Üren S. and Güvenç U. (2005) Biosorption of cadmium and lead ions by ethanol treated waste baker's yeast biomass, Bioresour. Technol., 96(1), 103-109.

Grimm A., Zanzi R., Björnbom E. and Cukierman A.L. (2008) Comparison of different types of biomasses for copper biosorption, Bioresour. Technol., 99(7), 2559-2565.

Hadi B., Margaritis A., Berruti F. and Bergougnou M. (2003) Kinetics and Equilibrium of Cadmium Biosorption by Yeasts Cells S. cerevisiae and K. fragilis, Int. J. Chem. Reactor Eng., 1, A47 (available at http://www.bepress.com/ijcre/vol1/A47)

Hawari A.H. and Mulligan C.N. (2006) Biosorption of lead(II), cadmium(II), copper(II) and nickel(II) by anaerobic granular biomass, Bioresour. Technol., 97, 692-700.

Herrero R., Lodeiro P., Rojo R., Ciorba A., Rodríguez P. and Sastre de Vicente M.E. (2008) The efficiency of the red alga Mastocarpus stellatus for remediation of cadmium pollution, Bioresour. Technol., 99(10), 4138-4146.

Hong Y. and Brown D.G. (2006) Cell surface acid-base properties of Escherichia coli and Bacillus brevis and variation as a function of growth phase, nitrogen source and $\mathrm{C}: \mathrm{N}$ ratio, Colloids Surf., $B, \mathbf{5 0}(2)$, 112-119.

Iconomopoulou M., Psarianos K., Kanellaki M. and Koutinas A.A. (2002) Low temperature and ambient temperature wine making using freeze dried immobilized cells on gluten pellets, Process Biochem., 37(7), 707-717.

Konstantinou M. and Pashalidis I. (2008) Competitive sorption of $\mathrm{Cu}(\mathrm{II}), \mathrm{Eu}(\mathrm{III})$ and $\mathrm{U}(\mathrm{VI})$ ions on $\mathrm{TiO}_{2}$ in aqueous solutions-A potentiometric study, Colloids and Surfaces A: Physicochemical and Engineering Aspects, 324, 217-221. 
Kopsahelis N., Agouridis N., Bekatorou A. and Kanellaki M. (2007) Comparative study of spent grains and delignified spent grains as yeast supports for alcohol production from molasses, Biores. Technol., 98(7), 1440-1447.

Kourkoutas Y., Komaitis M., Koutinas A.A. and Kanellaki M. (2001) Wine production using yeast immobilized on apple pieces at low and room temperatures, J. Agric. Food Chem., 49(3), 1417-1425.

Koutinas A.A., Papapostolou H., Dimitrellou D., Kopsahelis N., Katechaki E., Bekatorou A. and Bosnea L.A. (2009) Whey valorization : A complete and novel technology development for dairy industry starter culture production, Bioresour. Technol., 100, 3734-3739.

Lodeiro P., Herrero R. and Sastre de Vicente M.E. (2006) The use of protonated Sargassum muticum as biosorbent for cadmium removal in a fixed-bed column, J. Hazard. Mater., 137(1), 244-253.

Macaskie L.E. and Dean A.C.R. (1984) Cadmium accumulation by a Citrobacter sp., J. Gen. Microbiol., $130,53-62$.

Madigan M.T., Martinko J.M. and Parker J. (2000) Brock Biology of microorganisms, Ninth Edition, Prentice - Hall Inc., New Jersey, 135-162.

Markai S., Andrès Y., Montavon G. and Grambow B. (2003) Study of the interaction between europium (III) and Bacillus subtilis: fixation sites, biosorption modeling and reversibility, J. Colloid Interface Sci., 262(2), 351-361.

McKey G., Ho Y.S. and Ng J.C.P. (1999) Biosorption of copper from waste waters: a review, Sep. Purif. Rev., 28(1), 87-125.

Neale E.K. and Chapman G.B. (1970) Effect of low temperature on the growth and fine structure of Bacillus subtilis, J. Bacteriol., 104(1), 518-528.

Norberg A.B. and Persson H. (1984) Accumulation of heavy-metal ions by Zoogloea ramigera, Biotech. Bioeng., 26, 239-246.

Ozdemir G., Ceyhan N., Ozturk T., Akirmak F. and Cosar T. (2004) Biosorption of chromium(VI), cadmium(II) and copper(II) by Pantoea sp. TEM18, Chem. Eng. J., 102(3), 149-153.

Plessas S., Bekatorou A., Gallanagh, J., Nigam, P., Koutinas A.A. and Psarianos C. (2008) Evolution of aroma volatiles during storage of sourdough breads made by mixed cultures of Kluyveromyces marxianus and Lactobacillus delbrueckii ssp. bulgaricus or Lactobacillus helveticus, Food Chem., 107, 883-889.

Russell N.J. (2002) Bacterial membranes: The effects of chill storage and food processing. An Overview, Int. J. Food Microbiol., 79(1-2), 27-34.

Russell N.J, Evans R.I., ter Steeg P.F., Hellemons J., Verheul A. and Abee T. (1995) Membranes as a target for stress adaptation, Int. J. Food Microbiol., 28(2), 255-61.

Sarri S., Misaelides P., Papanikolaou M. and Zamboulis D. (2009) Uranium removal from acidic aqueous solutions by saccharomyces cerevisiae, debaryomyces hansenii, kluyveromyces marxianus and candida colliculosa, J. Radioanal. Nucl. Chem., 279(3), 709-711.

Shuttleworth K.L. and Unz R.F. (1993) Sorption of heavy metals to filamentous bacterium Thiothrix strain A1, Appl. Environ. Microbiol., 59, 1274-1282.

Umali L.J., Duncan J.R. and Burgess J.E. (2006) Performance of dead Azolla filiculoides biomass in Biosorption of Au from wastewater, Biotechnol. Lett, 28(1), 45-50.

Vasudevan, P., Padmavathy, V. and Dhingra, S.C. (2003) Kinetics of biosorption of cadmium on Baker's yeast, Bioresour. Technol., 89, 281-287.

Vázquez G., González-Álvarez J., Freire M.S., Calvo M. and Antorrena G. (2009) Determination of the optimal conditions for the adsorption of cadmium ions and phenol on chestnut (Castanea Sativa) shell, Global NEST Journal, 11(2), 196-204.

Vlachou A., Symeopoulos B.D. and Koutinas A.A. (2009) A comparative study of neodymium sorption by yeast cells, Radiochim. Acta, 97(8), 437-441.

Volesky B. (2003) Sorption and Biosorption. BV. Sorbex, Inc., Montreal, Canada.

Volesky B. and Holan Z.R. (1995) Biosorption of heavy metals, Biotechnol. Prog., 11(3), 235-250.

WHO (2008) Guidelines for drinking-water quality [electronic resource]: incorporating first and second addenda, vol. 1, Recommendations, 3rd edition (available at http://www.who.int/water_sanitation_health/dwq/fulltext.pdf) accessed 03/06/10)

Xie S., Yang, J., Chen C., Zhang X., Wang Q. and Zhang C. (2008) Study on biosorption kinetics and thermodynamics of uranium by Citrobacter freudii, J. Environ. Radioactiv., 99, 126-133. 